Table 1. Sex, age, percentage ideal body weight, fasting plasma glucose, fasting C-peptide, and coefficients of insulin sensitivity in subjects with or without residual B cell funtion

\begin{tabular}{|c|c|c|c|c|c|c|}
\hline & Sex & $\begin{array}{l}\text { Age } \\
\text { (years) }\end{array}$ & $\begin{array}{l}\text { Ideal } \\
\text { body weight } \\
(\%)\end{array}$ & $\begin{array}{l}\text { Fasting } \\
\text { glucose } \\
(\mathrm{mmol} / \mathrm{l})\end{array}$ & $\begin{array}{l}\text { Fasting } \\
\text { C-peptide } \\
(\mathrm{nmol} / 1)\end{array}$ & $\begin{array}{l}\text { Coefficients of } \\
\text { insulin sensitivity }\end{array}$ \\
\hline $\begin{array}{l}\text { With residual } \\
\mathrm{B} \text { cell function }\end{array}$ & $\begin{array}{l}6 \text { females } \\
6 \text { males }\end{array}$ & $33.0 \pm 2.4$ & $98.4 \pm 1.9$ & $7.66 \pm 0.22$ & $0.23 \pm 0.02$ & $2.25 \pm 0.64$ \\
\hline \multirow[t]{2}{*}{$\begin{array}{l}\text { Without residual } \\
\mathrm{B} \text { cell function }\end{array}$} & $\begin{array}{l}6 \text { females } \\
6 \text { males }\end{array}$ & $35.2 \pm 3.5$ & $96.3 \pm 2.2$ & $8.38 \pm 0.31$ & --- & $0.75 \pm 0.11$ \\
\hline & --- & NS & NS & NS & --- & 0.05 \\
\hline
\end{tabular}

Results expressed as mean \pm SEM. Statistical significance of differences calculated by Student's t-test for unpaired data

statements are valid. First, the majority of the patients had hypertriglyceridaemia associated with over-production of VLDL-triglyceride during the baseline period. Second, with energy restriction, VLDLtriglyceride production fell in the majority of the patients while there were quite variable changes in their fractional catabolic rates.

Sincerely,

Dr. H. Ginsberg

Division of Arteriosclerosis and Metabolism

Mount Sinai School of Medicine, New York

and

Dr. S. Grundy

University of Texas Health Science Center

Dallas, Texas

USA

\section{Residual B Cell Function and Insulin Sensitivity in Type 1 (Insulin-Dependent) Diabetes Mellitus}

Sir,

It is now well established that many Type 1 diabetic subjects continue to have some degree of residual B cell function [1]. The metabolic importance of this endogenous insulin production has been emphasized recently in Diabetologia [2]. However, the mechanism(s) whereby persistent B cell secretion may facilitate good metabolic control is poorly understood. Thus, it is of interest that we found a significant positive relationship between basal $B$ cell secretion rate and insulin sensitivity in Type 1 diabetic patients with detectable fasting C-peptide [3].

In the present study, we measured insulin sensitivity in two groups of 12 Type 1 diabetic subjects that differed with respect to residual B cell function. Twelve patients had evidence of residual B cell function, with fasting C-peptide $>0.40 \mathrm{ng} / \mathrm{ml}(0.13 \mathrm{nmol} / 1)$, assessed by the method of Kaneko et al. [4]. The other 12 individuals had undetectable C-peptide, both fasting and in response to IV glucagon. The two groups were similar in sex, age, body weight and plasma glucose concentration. No subject had a serum binding affinity for ${ }^{125}$ I-Insulin $>$ $10 \%[5]$.

The subjects stopped their regular insulin for $12 \mathrm{~h}$ and their longacting insulin for $48 \mathrm{~h}$ before the study. After an overnight fast, at $08.00 \mathrm{~h}$ they received a bolus IV injection of regular insulin (Actrapid MC, Novo, $0.1 \mathrm{IU} / \mathrm{kg}$ body weight). Blood samples were taken from an antecubital vein through an indwelling cannula kept patent by a slow $0.9 \%$ saline infusion before and $5,10,15,20,25,30,35,40$ min after the insulin injection. The glucose disappearance rate with time was calculated from 5 to $25 \mathrm{~min}$ after the insulin injection, and used as an index of insulin sensitivity as described by Alford et al. [6] and BeckNielsen et al. [7].
The diabetic subjects with residual B cell function showed significantly higher coefficients of insulin sensitivity than those without endogenous insulin secretion (Table 1).

The difference in insulin sensitivity may explain, at least in part, the lower insulin requirement and better metabolic control in those Type 1 diabetic subjects with residual B cell activity [2]. Indeed, a continued secretion of insulin into the portal vein and hence directly into the liver may be very important in controlling the hepatic abnormalities of diabetes $[8,9]$. In particular, persistent endogenous insulin production might help to suppress hepatic glucose production and to promote glucose uptake and disposal by the liver, muscle, and adipose tissue.

Yours sincerely,

E. Bonora, C. Coscelli and U. Butturini

\section{References}

1. Hoekstra JBL, Van Rijn HJM, Erkelens DW, Thijssen JHH (1982) C-peptide. Diabetes Care 5: 438-446

2. Madsbad S (1983) Prevalence of residual B cell function and its metabolic consequences in Type 1 (insulin-dependent) diabetes. Diabetologia 24: 141-147

3. Bonora E, Manicardi V, Coscelli C, Butturini U (1982) Relationship between basal B cell activity and insulin sensitivity in healthy, obese, and diabetic man. Diabetologia 23:156 (Abstract)

4. Kaneko T, Oka H, Munemura M, Oda T, Yamashita K, Suzuki S, Yanaihara N, Hashimoto T, Yanaihara C (1974) Radioimmunoassay of human proinsulin C-peptide using synthetic human connecting peptide. Endocrinol Jpn 21: 141-145

5. Christiansen AH (1973) Radioimmunoelectrophoresis in the determination of insulin binding to IgG. Methodological studies. Horm Metab Res 5: 147-154

6. Alford FP, Martin FIR, Pearson MJ (1970) The significance and interpretation of mildly abnormal glucose tolerance. Diabetologia 7 : 173-180

7. Beck-Nielsen H, Pedersen O (1978) Insulin receptors on monocytes of young healthy persons correlated with glucose tolerance and insulin sensitivity. Diabetologia 14: 159-163

8. Madsbad S, Faber OK, Kurtz A, Krarup T, Regeur L, Tronier B, Ørskov H, Binder C, Alberti KGMM (1982) The significance of the portal insulin secretion in insulin-dependent patients with residual beta-cell function: a safeguard against hormonal and metabolic derangement. Clin Endocrinol 16: 605-613

9. DeFronzo RA, Simonson D, Ferrannini E (1982) Hepatic and peripheral insulin resistance: a common feature of Type 2 (non-insulin-dependent) and Type 1 (insulin-dependent) diabetes mellitus. Diabetologia 23: 313-319

Dr. Enzo Bonora

Via Fabio Filzi, 15

I-46100 Mantova

Italy 